\title{
The praxis of digital literacy in the EFL classroom: Digital- immigrant vs digital-native teacher
}

\author{
Nia Kurniawati*, Elis Homsini Maolida, and Agung Ginanjar Anjaniputra \\ English Education Study Program, Faculty of Education and Teacher Training, Suryakancana University, \\ Cianjur, West Java, Indonesia
}

\begin{abstract}
Myriads of theories account for the primacy of digital literacy on ELT as the demand of the $21^{\text {st }}$ century, yet studies on digital media literacy of distinct English teacher generations are thin on the ground. Thus, this descriptive qualitative study investigated the utilization of digital literacy in the EFL classroom of senior high school teachers from two generations (digital immigrant and digital native) and their students' responses to the use of digital media in the English classroom in Indonesia. Three instruments were utilized including classroom observations, questionnaires, and interviews. Following ACOT's (Apple Classroom of Tomorrow) framework, the findings show that both teachers were at the adaptation stage in terms of digital literacy and this was reflected on the utilization of digital media in assisting students' learning. Yet, the digital-immigrant teacher appeared to be practically more adept in the implementation of digital media. As for the second issue, the students responded positively to the use of digital technology by the teachers to make English class more fun and comprehensible. However, when it comes to an ideal teacher, the students still considered good characters as the main criteria for an ideal teacher. Technology does support teachers in delivering the materials, but the way they behave and treat the students still also plays crucial part in maintaining a good relationship between teachers and students. The results show that the English teachers need to develop their digital literacy to keep up with the current demand to be professional English teachers in the digital era.
\end{abstract}

Keywords: digital media; senior high school teachers; digital immigrant; digital native; EFL

First Received:

5 January 2018

Final Proof Received: 27 May 2018

\section{Accepted:}

19 Apil 2018

Published:

31 May 2018

How to cite (in APA style):

Kurniawati, N., Maolida, E. H., Anjaniputra, A. G. (2018). The praxis of digital literacy in the Efl classroom: digital-immigrant vs digital-native teacher. Indonesian Journal of Applied Linguistics, 8(1), 28-37. doi: 10.17509/ijal.v8i1.11459

\section{INTRODUCTION}

Based on the data released by Indonesia's Ministry of Communication and Informatics (Suwana \& Lily, 2017) it was reported that in 2014 Indonesia became the eighth highest number of the Internet users in the world which shows an immense growth in Internet use in Indonesia. In this case, digital devices progressively permeate in almost every aspect of daily life and they have changed the way people access and share information. Besides the fact that computers and the Internet have become prevailing technology in learning process, digital tools also have transformed the process in which people construct, process and communicate knowledge (Gialamas, Nikolopoulou, \& Koutromanos, 2013). In this regard, it is inevitable that today people should acquire digital media literacy as one of major competences (Ferrari, 2013) and 21st century teachers are challenged to integrate digital literacy in teaching learning process. As digital literacy becomes a focal competence in today's life, it has attracted a lot of 
scholars to conduct various studies including the evaluation of students' digital literacy (Zhang \& Zhu, 2016) as well as the utilization of digital tools in classroom setting (Hobbs, 2013; Park \& Burford, 2013; Nowell, 2014; Young, 2008). Thus, digital literacy is required for teachers to conform to students' digital inclination and necessities in the classroom.

Regarding digital literacy, scholars have used various terms and definitions. Several terms such as 'ICT literacy,' 'digital competence' and digital literacy often generally refer to exchangeable technological use and ability eventhough they are sometimes utilized with different focus and scope. Educational Testing Service (2007) defines 'ICT literacy' as use of digital technology, communication devices and networks to get, control, incorporate, estimate and generate information in a society of knowledge. Meanwhile, Ferrari (2013) utilizes another term 'digital competence' that can be summarized as the competence to manage communication, information, content design, and problem handling. More specifically, Hatlevik and Christophersen (2013) define digital competence as the skill to utilize technology to gain, manage and evaluate information, create and share information by using digital tools.

As for 'digital literacy', Twing (2013, in Zhang \& Zhu, 2016) describes it as the skill to be an effective citizen in the 21 st century, including comprehending the characteristics and features of digital technology and the effect of digital identities, having the ability to manage, comprehend, assess, share and communicate information using digital technology as well as interact in the digital world safely. Within the context of this study, Koltay's definition (2011) of 'digital literacy' that refers to the efficient utilization of information and communication technology (ICT) is closer to our aim to specifically focus on the teachers' use of digital media in EFL teaching and learning process.

The success of digital literacy in classroom settings is often related to teachers' key role as a facilitator in teaching learning process. Young (2008) states that teachers, students, and overall technology use rely on how a teacher utilizes the technology in the classroom, so the lack of teacher competence becomes a major obstacle in technological device application in teaching learning process. In this case, generation gap and digital divide become an important issue. According to Park and Burford (2013), digital divide can be summarized as the gap between those who can and cannot operate in the digital era and the gap between those who can and cannot access information through digital technologies and this term is often related to generation gap that represents technology generations, where the digital native generation are often considered more digital savvy than their previous generation, digital immigrant.

Oblinger and Oblinger (2012) have classified technology generations into four groups: 'mature' for those who were born between 1900-1946, 'baby boomers' a generation born between 1946-1964, 'generation x' or 'digital immigrant' who were born between 1965-1982 and 'net generation', 'millenials' or 'digital native' who were born between 1982-1991. Within the context of technological tools and processes, various generations of people experienced different technologies during their influential years. Hartman, Moskal, and Dziuban (2005) explain that the 'mature' generation familiar with some technologies such as vacuum-tube radios, manual calculators, and dial telephones while 'Baby Boomers' are accustomed to transistor radios, mainframe computers, and the touchtone telephone. Gen-X 'digital immigrant' grew up in the era of CDs, personal computers, and electronic mail. For the Net Generation 'digital native', they are surrounded by PDAs, MP3s, and cell phones. In that case, instant messaging, text messaging, and blogs characterize the way the digital native communicate (Hartman et al., 2005). Within the context of teaching and learning, several studies raise the issue of the digital gap between different technology generations, especially between 'digital immigrant' and 'digital native' since both generations dominate the population of today's educational setting.

In a highly cited article, Prensky (2001) delineates digital gap between digital immigrant teachers represented as the generation who "speak an outdated language (that of the pre-digital age), are struggling to teach a population that speaks an entirely new language" (p.3) with their digital native students described as "a native speakers of the digital language of computers, video games and the Internet ... no longer the people our educational system was designed to teach" (p.2). Concerning the gap, Prensky (2001) suggested the digital immigrant teachers to reconsider their teaching methodology and content to suit their digital natives' need. Other studies (Raman \& Yamat, 2014; Williams, 2012) that show the generation gap toward technology indicate the difference in terms of attitude toward technology between digital immigrant teachers and their digital native students.

Raman and Yamat (2014) who investigated twelve English teachers regarding the barriers in implementing ICT revealed that one of the barriers was teacher's age in which older teachers with more teaching experience did not favor the integration of ICT tools in their classroom due to their critique to themselves as being too old for new technologies and their beliefs on the effectiveness of traditional teaching method. In addition, Williams (2012) who studied perceptions of digital immigrant teachers toward their digital native students' use of social media showed that even though they had positive perceptions on social media use in terms of collaboration, teacher student relations, and communication, at the same time they gave negative perception in terms of improperness of formal writing, meager interpersonal communication skill, and too much drama. In this regard, such drawbacks of social media can result in alterations of students' affective and cognitive behaviour. Besides, as for teachers, this 
negative perception might reduce their awareness of the primacy of technology in the classroom.

However, some articles have different perspectives and results. Adams and Pente (2011) question the dualism portrayal between digital immigrant and digital native teachers given by Prensky (2001) as it can put an unhelpful distance between generations and they remind teachers not to uncritically adopt all the new technologies without careful and multiple considerations. Insignifficant effect of the generation gap is also shown by Ferrero (2002) who investigated two teacher generations for their attitude differences toward ICT and found out that positive attitude toward ICT was more influenced by teachers' personal history and teachers' experience in technologal trainings. She revealed that the generation gap did not give any sistematic effect on how the teachers engage ICT in their teaching. Apart from the various conclusions and recommendations, these studies mostly focused on the generation gap between digital immigrant teachers and digital native students. Even though a work covers up the generation gap between different teacher generations, the study put its emphasis on teachers' attitude, not their teaching practice. This study will have its contribution by revealing teachers' practice of digital literacy in English classroom.

In describing the praxis of digital literacy of digital immigrant and digital native teachers in their EFL classroom, Apple Classroom of Tomorrow's (ACOT) framework is employed. Originated by Apple Classroom of Tomorrow project, a series of technology utilization for teaching and learning is categorized into five classifications: Entry, Adoption, Adaptation, Appropriation, and Invention (ACOT, 1996). These developmental stages denote a continuum of how teachers make effective use of technology aiding the teaching and learning process with the entry stage as the nethermost level and the invention stage as the pinnacle of deployment of technology.

The entry stage constitutes teachers' knowledge of technology, in which teachers are coping with how to use the technology (ACOT, 1996; Muir-Herzig, 2004; Brooks-Young, 2007). At this stage, teachers are said to be uncertain about technology which could be employed in their classrooms. According to Rein (2000), the entry-level teachers are signified by their withdrawal of using digital media and fear of students' use of technology. He affirms that this results from their concern about technology as tools unmanageable by them. The teachers tend to use direct instructions and traditional method to present materials to students.

Slightly above the entry level is the adoption stage in which teachers are willing to use technology to assist students' learning instead of solely employing whole class activities and traditional instruction (Muir-Herzig, 2004). In contrast to the entry stage which is indicated by teachers' unwillingness to use technology due to their incapability to manage it, teachers at this stage seemingly start to have confidence to adopt and operate it. In other words, teachers incorporate technology deemed manageable by and useful for them. It is exemplified that teachers may use the technology as preparation or create quizzes and worksheets for students with the aid of computers (Rein, 2000; BrooksYoung, 2007). Thus, there is no doubt in teacher to use software applications, computers, and even the Internet.

In addition, at the adaptation stage, teachers make an attempt to realize the integration of new technology into their teaching (ACOT, 1996; Rein, 2000; MuirHerzig, 2004; Brooks-Young, 2007). This stage denotes the improvement of students' productivity in terms of the rate and engagement of learning in a variety of contexts (ACOT, 1996; Muir-Herzig, 2004). This improvement of students' learning experience is caused by allowing students to use technology in the procees (Rein, 2000), which is hardly facilitated by the two previous stages. It is common to have students complete their assignments by making use of computers.

Regarding the next stage, which is the appropriation stage, ACOT (1996) and Brooks-Young (2007) believe that teachers put emphasis on technology use to help students in collaborative and project-based learning at this stage. Besides, this collaborative learning in terms of students' work patterns and interaction, as stated by Muir-Herzig (2004), replaces competitiveness among them. This is in line with Rein's (2000) argument affirming that collaborative and cooperative learning, high order thinking, problem solving, and enhanced comprehension are largely facilitated. Furthermore, he further argues that the salient features of teachers at this stage are when considerations of learning objectives are of utmost importance to seek the best way to pursue the objectives and to determine the best tools for it.

At the invention stage, teachers are ready to develop technology for a number of functions in the classroom such as creating projects through the combination of multiple technologies (ACOT, 1996; Brooks-Young, 2007). This is in harmony with MuirHerzig's (2004) argument that technology at the invention stage is used as a flexible tool to create active and socially interactive learning. Moreover, teachers at this stage enable students to construct their knowledge (Rein, 2000; Muir-Herzig, 2004). Furthermore, due to teachers' successful transition to ultimate utilization of technology, technology prevalence in the classroom is inextricably linked to the curriculum (Rein, 2000).

By using the ACOT framework, this study delineates how a digital-immigrant teacher and a digitalnative teacher manifest the concept of digital literacy in their EFL classrooms and the students' responses to the praxis of digital literacy in the classroom. Notwithstanding numerous studies on digital literacy in classroom settings (see Zhang \& Zhu, 2016; Park \& Burford, 2013; Young, 2008; Nowell, 2014; Hobbs, 2013) and the difference between technology generations in using technological devices in educational settings (see Prensky, 2001; Raman \& Yamat, 2014; Williams, 2012; Ferrero, 2002), studies that investigate digital literacy levels viewed from 
different technology generations among teachers as well as their students' responses are scarce. Therefore, this study attempts to investigate the stages at which teachers from two distinct technology generations manifest their digital literacy in EFL teaching practice and how the students respond to it.

\section{METHOD}

This study was carried out based upon descriptive study to portray teacher's digital literacy seen from how digital-immigrant and digital-native teachers utilize digital media in their classroom. Descriptive study complies with the purpose of the research in a way that it is specifically intended to describe a phenomenon as it is, comprising the description, recording, analysis, and interpretation of the present nature of or processes of phenomena. The focus is on prevailing circumstances, or how a person, group, or thing behaves or acts at a particular time (Jackson, 2009; Salkind, 2017) and it often involves some type of comparison or contrast (Manuel \& Medel, n.d., cited in Joy, 2014). The nature or processes investigated in this study was the process of teaching and learning focused on the manifestation of digital literacy of teachers as it is implemented in the classroom. Besides, comparison and contrast were also featured in this study as this attempts to portray the praxis of digital literacy of two distinct generations of teachers.

Depicting the praxis of digital literacy in a senior high schools of a regency in West Java, Indonesia, the present study drew on three considerations in deciding on the research site. Firstly, digital media literacy becomes a newly prevailing issue in the educational field, so such a study will be carried out at a level where English has become a compulsory subject as delineated in the curriculum, prior to conducting it in vocational senior high schools. Secondly, regarding the object of this study, digital media literacy, the school selected has requisite facilities to implement it. Thirdly, as for the regency of undertaking this study, a comprehensive study on digital media literacy involving a digitalimmigrant teacher and a digital-native teacher has never been thick on the ground if not scarcely conducted beforehand. Thus, the execution of this study will have a significant stimulus not only for teachers in the region but also those in general.

\section{Participants}

Participants involved in this study were two senior high school English teachers and 20 of their students. The selection of the participants was based upon purposeful sampling. It refers to a sampling strategy to intentionally include individuals into the study by considering the provision of useful information to develop detailed understanding regarding the study under investigation (Creswell, 2012). As this study put emphasis on the digital literacy manifested in the classroom, the two teachers were chosen for their inclination to make effective use of digital media in their classrooms. Besides, two distinct teacher generations were involved to provide the depiction of their digital literacy as they implemented it in the class. In the meantime, students involved in this study were those from the classes that the two teachers taught. This is particularly useful to gain information about their learning experience as exposed to digital media.

\section{Instruments}

Regarding the data collection techniques, classroom observation triangulated with teacher interview and questionnaire were deployed to ascertain that the praxis of digital media utilization could be depicted. Videotaped classroom observation was chosen as the key instrument to get a clear picture of exact occurrences of teaching learning activities. The observation was intended to understand the culture, setting, or social phenomenon being studied from the perspectives of the participants (Hatch, 2002), in this sense the understanding of how EFL teachers across generations manifest their digital literacy in the classroom contexts. Data that are hardly obtained through interview can well be observed (Hatch, 2002; Cohen, Manion, \& Morrison, 2007), resulting in comprehensive understanding of the activity or behavior and its elements under investigation (Fraenkel, Wallen, \& Hyun, 2012). In the meantime, for eliciting students' responses, interview and questionnaire were triangulated to yield the general pattern of responses towards digital media utilization in the classroom.

\section{Procedures}

Data collection of the teachers was carried out in advance of students' response elicitation, starting from administering classroom observation, interview and questionnaire accordingly. The results of these were then transcribed for coding to locate relevant behavior of the teachers concerning the utilization of digital media as their manifestation of digital literacy. Following this, the student interview and questionnaire were done subsequently. These had the same purpose of understanding their responses on the manifestation of their teachers' digital literacy.

\section{Data analysis}

Following Malik and Hamied's (2014) coding method by classifying themes based upon their recurrence, this study analyzed the data in compliance with two frameworks that encompass the one firstly developed by Apple Classroom of Tomorrow (ACOT, 1996) project to portray digital media utilization and and the other one of which was proposed by Zhang and Zhu (2016). ACOT's (1996) framework entails five stages of teachers' digital media use: the entry, adoption, adaptation, appropriation, and invention. Each activity in the class relevant to and concerned with the utilization of both offline and online technology was categorized into one of those five stages. Likewise, the analysis viz-a-viz how students respond to teachers' efforts of deploying technology was based upon 
categories two of which were adopted from Zhang and Zhu's (2016) framework: digital media experience and parental mediation. Some modifications were applied in terms of the context which is solely in the classroom during the lesson, so parental mediation was intentionally changed into teacher mediation. Thus, the framework for eliciting students' responses encompasses students' digital media experience, deployment of online technology, deployment of offline technology, paper-based media, awareness of technology aid to language skills, and teacher mediation.

\section{FINDINGS AND DISCUSSION}

This section presents findings and discussion of the study regarding the praxis of digital literacy of teachers from two distinct generations. This concerns how two teachers manifest their understanding of digital media in the classrooms as well as how students respond to variety of media made use of by the teachers.

\section{The praxis of digital literacy in the classrooms}

This part of the research concerns data obtained mainly from classroom observations and enriched with the results of the questionnaires from and interview of two English teachers of a senior high school. The data are categorized based upon the five stages of digital utilization originally proposed by ACOT (1996), encompassing the entry, adoption, adaptation, appropriation, and invention stages. The categorization is used to draw on learning activities and use of technology in the classrooms as an indicator of digital literacy possessed by the teachers. The findings are summed up accordingly in Table 1.

Table 1. Five stages of teachers' technology integration

\begin{tabular}{|c|c|c|c|c|c|c|}
\hline \multirow{2}{*}{ Teacher } & \multirow{2}{*}{ Learning activities } & \multirow{2}{*}{ Use of technology } & \multicolumn{4}{|c|}{ Five stages of technology integration } \\
\hline & & & Entry & Adoption & Adaptation & Appropriation \\
\hline \multirow[t]{6}{*}{$\begin{array}{l}\text { The digital- } \\
\text { immigrant teacher }\end{array}$} & Delivering apperception & $\begin{array}{l}\text { LCD projector and } \\
\text { presentation software }\end{array}$ & & $\sqrt{ }$ & & \\
\hline & $\begin{array}{l}\text { Giving instruction and } \\
\text { explanation }\end{array}$ & $\begin{array}{l}\text { LCD projector and } \\
\text { presentation software }\end{array}$ & & $\sqrt{ }$ & & \\
\hline & Providing printed tasks & Word processor & & $\sqrt{ }$ & & \\
\hline & $\begin{array}{l}\text { Giving instruction of main } \\
\text { practice }\end{array}$ & $\begin{array}{l}\text { LCD projector and } \\
\text { presentation software }\end{array}$ & & $\sqrt{ }$ & & \\
\hline & Completing a sentence & A digital dictionary & & & $\sqrt{ }$ & \\
\hline & $\begin{array}{l}\text { Assigning students to finish } \\
\text { their presentation media }\end{array}$ & Presentation software & & & $\sqrt{ }$ & \\
\hline $\begin{array}{l}\text { The digital-native } \\
\text { teacher }\end{array}$ & Writing a paragraph & digital dictionaries & & & $\sqrt{ }$ & \\
\hline
\end{tabular}

Table 1 depicts digital media utilization of the two teachers as captured during the classroom observation. Albeit a generational distinction between them, they have something in common that they are in the adaptation stage, seen from their teaching practices and activities and techniques employed in the classrooms. This result conforms to Rein's (2000) conclusion that most educators are not ready to have made effective use of technology in the stages of appropriation and even invention. This might be due to lack of technological trainings that enable them to reach particular standards. However, their integration of technology in the classrooms looks promising although some required facilities in the school have not been yet met.

To discern how each teacher manifested technology in the classrooms, the next two sub-sections are going to elaborate it.

\section{The digital-immigrant teacher's digital literacy}

How the teacher manifests digital literacy in her classroom is observed, which is categorized into the stages of adoption and adaptation. This was in accordance with activities and techniques to help the students to learn English. During the observation, the teacher was known to realize her digital literacy categorized into the adoption stage four times and into the adaptation stage twice. The adoption stage of the teacher could be noticed when she delivered the teaching materials by using a laptop computer, Microsoft PowerPoint and an LCD projector. Although the teacher focused on these three tools of technology, she was capable of providing different functions and means of learning. In this sense, the adaptation stage was noticeable when the teacher had the students use technological software to improve and ease their learning.

With regard to the adoption stage of the teacher, the activities comprised delivering apperception, giving instruction and explanation, providing printed tasks, and giving instruction of main practice. In the apperception or prior to the main activities, the teacher showed the students the lesson objectives of that time through an LCD projector. As the teacher used the technological tool, it could be seen that she was so certain about using it. The teacher could handle it herself. There was no sign of hesitation or incapability of operating the technological tools. This indicates a characteristic of adoption stage in which teachers are willing to use technology to assist students' learning instead of solely employing whole class activities and traditional instruction (Muir-Herzig, 2004), due to their capability and confidence to operate it. In addition, her seemingly 
effortless attempt to use such tools even for the preliminary stage of teaching to some extent provides students with clear purposes of what the students must be able to do. Without the clarity of the objectives, students may be confused about what to do and how to perform.

In addition, for each activity conducted in the classroom, the teacher gave the instructions orally as well as, most importantly, visually with the merit of LCD projector. Instructions are also crucial in ensuring that the students carry out activities well and on the track. The use of LCD projector in giving instructions to the students is likely to draw students' attention as Microsoft PowerPoint slides projected onto a big screen are more attractive than written texts on whiteboards.

The teacher also was seen to give students different pieces of paper containing incomplete sentences for students. Instead of instantly writing the incomplete sentences, the teacher had prepared some pieces of paper beforehand, typed and printed. This is also a manifestation of the adoption stage as exemplified by Rein (2000) and Brooks-Young (2007) that teachers may use the technology as preparation or create quizzes and worksheets for students with the aid of computers (Rein, 2000; Brooks-Young, 2007). In this regard, the teacher prepared the worksheets on little pieces of paper.

As aforementioned, the adaptation stage was also manifested in the classroom activities, particularly when the teacher asked students to use some technological tools in assisting their learning. Allowing students to use technology in the process of learning is expected to stimulate students' productivity in terms of the rate and engagement of learning in a variety of contexts (Rein, 2000), which constitutes an indication of realization of the adaptation stage (ACOT, 1996; Muir-Herzig, 2004). In the learning process, the teacher asked students to use an electronic dictionary on their phone and in another meeting, to utilize the PowerPoint slides to finish their works. Notwithstanding permission to use a dictionary on the phone, the teacher restricted the use of smartphone by the prohibition of the Internet. This indicates the teacher's awareness of probable drawbacks of technology in learning. How the teacher integrated technology at the adaptation stage is shown below.

T1: The time starts... seven minutes yeah, please write down its description, don't forget to write "used to" or "used for"

T1: okay, you are, please pay attention! You are allowed to open Kamusku, you can open Kamusku. no Google Translate. you are only allowed to open Kamusku. For those who bring gadget, you can open Kamusku. Kamusku! No Google Translate, are you ready?I begin from...now!

The excerpt above depicts that the teacher mediates the use of technology in the classroom for optimal learning experience by allowing students to use an electronic dictionary. The teacher also limited the use of technology by inhibiting the use of Google Translate and restricting the time for the practice. Hence, the students successfully pulled through difficult learning situations and redundancy of information could be disposed of. In general, this result shows that the teacher has surpassed the entry stage of digital literacy with the later stage of adoption and adaptation.

\section{The digital-native teacher's digital literacy}

Compared to the digital-immigrant teacher, this digitalnative teacher did not have as much as experience of teaching. Particularly in integrating technology the teacher seemed to have been accustomed to the use of paper-based media. This was shown by limited use of technology in the classroom. The only technology integration observed during the observation was of the adaptation stage. At the adaptation stage, teachers make an attempt to realize the integration of new technology into their teaching (ACOT, 1996; Rein, 2000; MuirHerzig, 2004; Brooks-Young, 2007). It was reflected in an activity that assigned the students to write a paragraph. In this activity, students used dictionaries on their phones to help them find appropriate words to write. Despite students' use of dictionary, the teacher did not seem to directly allow for dictionary use nor to prohibit its use.

One thing to note is that although the first teacher also utilized technology at the adaptation stage, as this one did, an apparent difference can be recognized. It has something to do with the way the teacher mediated the use of technology in the classroom. The former teacher tried to restrict the use of it, as opposed to getting students spoon-fed by virtue of its use, by limiting the time and by prohibiting the use of Google Translate so that the students experienced the learning as well as its process accordingly. Meanwhile, the latter seemed to abandon this mediation. This occurrence is likely to have an association with how ones view technology. Moreover, the use of traditional instructions dominated the learning activities carried out by the digital-native teacher.

The findings are quite surprising that the digitalnative teacher, the one who has grown up alongside the era of many technological inventions, appeared to have negligence and reluctance to implement digital media. He applied mostly non digital media in teaching English in the EFL classroom. Despite the facts that his view was open to technological use in the classroom and also he was, to some extent, digital-literate, only limited digital media were utilized. The main reasons of the phenomena can be lack of training and experience in applying the digital media in teaching-learning activities. In this regard, experience and training on digital media can help teachers to refine knowledge and sharpen intuition of deploying the best possible digital tools in the classroom. Another way to be able to determine whether or not a technology is appropriate for learning is for teachers to experience learning through the technology (see Hubbard, 2004). This involves teachers assuming the role of a learner, either through 
enrolling in a course to learn something new or attempting to undertake activities that they intend to use for their students seen from a learner's perspective. This allows teachers to get a better picture of how learners may feel about using the tools, including what they find difficult to use or understand. Therefore, a range of digital media can be utilized by teachers to meet the demand of today's generation.

\section{Students' reponses to the praxis of digital literacy in the EFL classroom}

The second issue of this study is the students' response to the praxis of the digital literacy in EFL classroom. The findings from the interview and questionnaire in Table 2 reveal several interesting facts.

Table 2. Students' reponse to the practice of digital literacy in the classroom

\begin{tabular}{r|lc}
\hline \multicolumn{1}{c}{ No } & \multicolumn{1}{c}{ Categories } & Percentage \\
\hline 1. & Students' digital media experience & $72.90 \%$ \\
2. & $\begin{array}{l}\text { Students' response towards teachers' } \\
\text { deployment of online technology }\end{array}$ & $82.38 \%$ \\
3. & $\begin{array}{l}\text { Students' response towards teachers' } \\
\text { deployment of offline technology }\end{array}$ & $79.88 \%$ \\
4. & $\begin{array}{l}\text { Students' response towards paper- } \\
\text { based media }\end{array}$ & $71.40 \%$ \\
5. & $\begin{array}{l}\text { Students' awareness of technology aid } \\
\text { to language skills }\end{array}$ & $84.75 \%$ \\
6. & Teacher mediation & $76.50 \%$ \\
\hline
\end{tabular}

From Table 2, it can be seen that most students have a huge amount of time of digital media experience $(72.9 \%)$. It implies that the students were used to utilizing computer and the Internet in their daily activities. They used email and online chatting to communicate with their teacher and friends. They enjoyed learning through videos and other visual media given by the teacher, and they learned new things on line. This finding is in line with IEAB's (2008) finding that on average, millennials spend 6.5 hours each day saturated in print, electronic, digital, broadcast, and news media. They listen to and record music; view, create and publish Internet content; play video games; watch television; talk on mobile phones and send instant messages every day.

Not too different from digital media experience, the students also respond positively to the deployment of online technology (82.38\%). They used on line tools such as Whatssap and Line to chat with other students, used handphone intensively, and preferred on line than off line media. Perhaps because home computers and the Internet have become almost as prevalent as the telephone, instant messaging is a common communication and socializing mechanism such as Whatsapp and Line. Not only are Whatssap and Line accessible, they can support multiple, simultaneous conversations.

This is also supported by Oblinger and Oblinger (2012). They found that when teenagers are asked what they want from the Internet, the most common response is to get "new information". Close behind, at about 75 percent, is to "learn more or to learn better". The use of the Internet to learn is not limited to school work. Students are often informal learners, seeking information on a variety of topics, such as personal health. Other common activities involve participating in online communities, showing others what they can do, or voicing their opinions (Grunwald, 2003).

Besides on line technology, the use of offline technology is still favorable, too. The students' response towards teachers' deployment of offline technology is $79.88 \%$. The students still enjoy Microsoft PowerPoint, videos, songs, and films in their learning. They mentioned it was helpful when teachers used Microsoft PowerPoint in explaining the material. The students explained that the two teachers had involved technology into their teaching. The media the teachers commonly utilized were Microsoft PowerPoint, film, song, and some social media applications such as Line, email, and Whatsapp, and they often combined them with pictures. Sometimes, they also used conventional media such as whiteboard or flashcards in the teaching. In sum, as can be seen in Figure 1, the students mentioned that $70 \%$ of the classroom activities have involved on line technology, 20\% utilized Microsoft PowerPoint and other off line media such as film and song, and $10 \%$ used whiteboard and pictures in the English classroom.

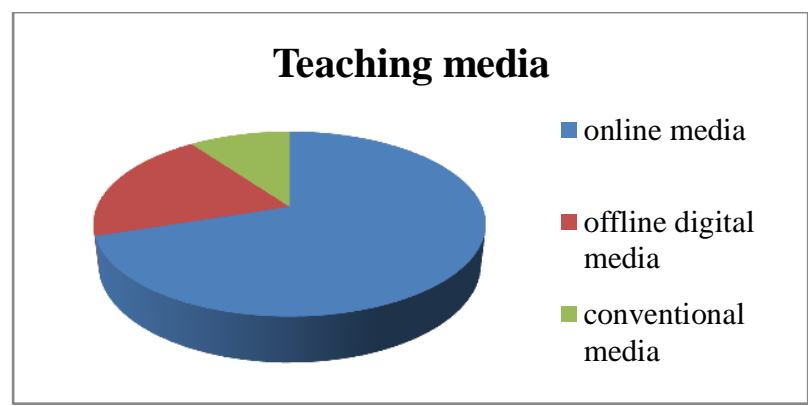

Figure 1. The use of teaching media by the teachers

This finding is in line with what Baker (2010) states that educators in the 21 st century are slowly starting to appreciate that we no longer live solely in a print-centric world; we are surrounded by a culture filled with visual images and messages, many of which work on a subconscious level. In the 21 st century, "texts" and "literacy" are not limited to words on the page: they also apply to still and moving images, such as photographs, television, and films. Today, being literate also means understanding wikis, blogs, bings, digital media, and other new and emerging technologies. From the fact in the figure, it shows that the teachers realize that they have to adapt to the $21 \mathrm{st}$ century teaching style that incorporates technology very intensively. They realize that the students now should be "entertained" with moving images, such as photographs, television, and films as well as wikis, blogs, bings, digital media, and other new and emerging technologies. Therefore the students as digital generation could be facilitated properly in the learning 
process. The students also realized the use of technology aid to language skills $(84.75 \%)$. They responded positively to the use of on line and off line technology in the language classroom. They agreed that the use of technology would help them to learn the four language skills (listening, reading, speaking, and writing).

For the teacher mediation aspect, the students agree that the teachers have done their best in mediating the students in technology use $(76.5 \%)$. The teachers organized time for the use of on line technology. The teachers also provided time for discussion and assistant while doing classroom activities that incorporated technology. As it is discussed earlier by Baker (2010) that proficient 21 st century teachers should know how to meet teaching standards, including those that today make more references than ever to media and multiliteracy. The problem is that many teachers are not proficient in teaching multiliteracy. Few educators have been trained in the effective use of media in instruction. Fewer still do not know how to embrace youth media and culture to engage students in learning. What Baker underlined that fewer still do not know how to embrace youth media and culture to engage students in learning is in line with the current condition in this study. The teachers use Microsoft PowerPoint a lot, and assume that the software is so advanced and the students also perceive it that way. Yet, there are still many things going on in involving technology into English classroom that can make the EFL learning even much more interesting.

From the interview, as shown in Figure 2, it reveals that the students have their expectation of what an ideal English teacher is. $40 \%$ of the students mentioned that the ideal teacher was the one who involved technology, and who was creative and innovative on the EFL classroom. While $60 \%$ of the students mentioned that the ideal teacher was the one with good characters such as intelligence, patience, and understanding of the students' personalities.

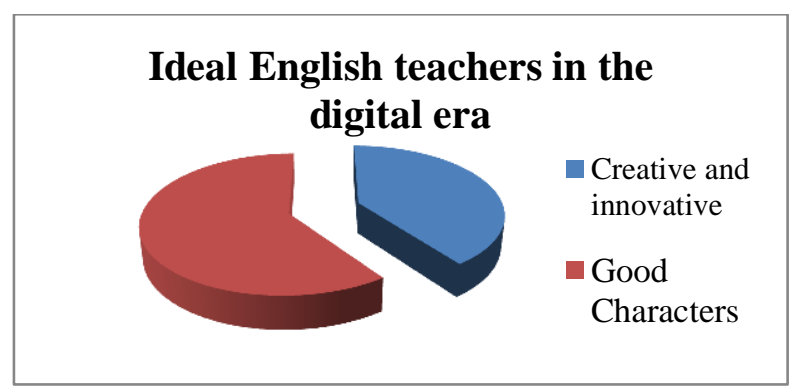

Figure 2. Ideal English teachers in digital era

Talking about ideal English teacher in any context, it is interesting to find out that even in the digital era, good characters still encompass other criteria. It is true that the teachers are demanded to follow the time advancement or in other words be creative and innovative. The students mentioned that they enjoyed the class when the teachers incorporated technology into their English class, explained the material using screen
O'matic, e-book, or virtual forum, and allowed the students to contact them via social media. Yet, when it comes to an ideal teacher, the students still consider good characters as the main criteria for ideal teachers. Technology does support teachers in delivering the materials, but the way they behave and treat the students still also plays crucial part in maintaining a good relationship between teachers and students.

\section{CONCLUSION}

As the praxis of digital litreacy performed by the English teachers from two different generations has been investigated, the conclusions are drawn in accordance with the findings and discussion previously presented. First, both teachers were at the adaptation stage in terms of digital literacy implementation. They deployed digital media with some limitations in terms of its intensity and frequency. Their digital literacy has been narrowly manifested in the classroom despite the fact that the digital-immigrant teacher appeared to be practically more adept in the implementation of digital media and that the teachers were aware of this benefits and the demand of the generation "Z." Besides, teachers growing up in the digital era and exposed to the rapid ever-changing technology do not guarantee that their developmental stages of digital literacy are superior. Instead, experience and teacher training seem to be essential.

Second, the students responded positively to the digital literacy praxis in the classroom, and they demanded creative and innovative learning activities which involved not only a single mode of meaning making but also the combination of audio, visualization, and motion. They favor the use of combination between on line and off line technology since they are categorized as digital native where technology has been in their DNA. Yet, when it comes to an ideal teacher, the students still consider good characters as the main criteria for ideal teachers. Technology does support teachers in delivering the materials, but how teachers behave and treat students still also plays a crucial role in maintaining a good relationship between teachers and students.

\section{ACKNOWLEDGEMENT}

We would like to extend our sincerest gratitude to the faculty of education and teacher training of Suryakancana University that has funded this reserach, and also SMA Negeri 2 Cianjur English teachers and students who had willingly involved in this study.

\section{REFERENCES}

ACOT. (1996). Teaching learning and technology: A report of 10 years of ACOT research. Apple Computers Inc.

Adams, C.A., \& Pente, P. (2011). Teachers teaching in the new mediascape: Digital immigrants or 
'natural born cyborgs'? E-Learning and Digital Media, 8(3), 247-257.

Baker, F. W. (2010). Media literacy: 21st century literacy skills. H. H. Jacobs, (eds.). Curriculum 21: Essential education for a changing world (pp. 133152). Alexandria: ASCD publications.

Brooks-Young, S. (2007). Digital-age literacy for teachers: Applying technology standards to everyday practice. Eugene, Oregon: International Society for Technology in Education.

Cohen, L., Manion, L., \& Morrison, K. (2007). Research methods in education. London: Routledge.

Creswell, J. W. (2012). Educational research: Planning, conducting and evaluating quantitative and qualitative research ( $4^{\text {th }} \mathrm{ed}$.). Boston: Pearson Education, Inc.

Educational Testing Service. (2007). Digital transformation: A framework for ICT literacy. A report of the international framework for ICT literacy. Educational Testing Service. Retrieved from

https://www.ets.org/Media/Tests/Information_and _Communication_Technology_Literacy/ictreport.p df

Ferrari, A. (2013). DIGCOMP: A Framework for developing and understanding digital competence in Europe. Luxembourg: Publications Office of the European Union. doi:10.2788/52966

Ferrero, S. (2002). Two generations of teacher differences in attitudes towards ICT. Retrieved November, 10, 2017, from http://www.oerafrica.org/FTPFolder/guyana/CCTI $\% 20 \mathrm{CD} / \mathrm{CCTI} \% 20 \mathrm{CD} /$ ukzncore1b/documents/cor e1b.Teachers-Generation.pdf

Fraenkel, J. R., Wallen, N. E., \& Hyun, H. H. (2012). How to design and evaluate research in education (8th ed.). New York: Mc Graw HIll.

Gialamas, V., Nikolopoulou, K., \& Koutromanos, G. (2013). Student teachers' perceptions about the impact of internet usage on their learning and jobs. Computers \& Education, 62, 1-7. doi:10.1016/j.compedu.2012.10.012

Grunwald, P. (2003, September). Key technology trends: excerpts from new survey research findings. Exploring the Digital Generation, Educational Technology, U.S. Department of Education, Washington, D.C., September 23-24, 2003

Hartman, J., Moskal, P., \& Dziuban, C. (2005). Preparing the academy of today for the learner of tomorrow. In D. G. Oblinger \& J. L. Oblinger (Eds.). Educating the net generations (pp. 6.16.15). Educause. Retrieved October 1, 2012, from http://www.educause.edu/educatingthenetgen/

Hatch, J. A. (2002). Doing qualitative research in education settings. New York: State University of New York Press.

Hatlevik, O. E., \& Christophersen, K.-A. (2013). Digital competence at the beginning of upper secondary school: Identifying factors explaining digital inclusion. Computers \& Education, 63, 240-247. doi:10.1016/j.compedu.2012.11.015.

Hobbs, R. (2013). Improvization and strategic risktaking in informal learning with digital media literacy. Learning, Media and Technology, 38(2), 182-197. doi: 10.1080/17439884.2013.756517

Hubbard, P. (2004). Learner training for effective use of CALL. S. Fotos \& C. Browne (Eds.), New perspectives on CALL for second language classrooms (pp. 45-68). Mahwah, NJ: Lawrence Erlbaum.

IEAB. (2008). Learning in the $21^{\text {st }}$ century: Teaching today's students on their terms. International Education Advisory Board. Retrieved from https://www.certiport.com/Portal/Common/Docum entLibrary/IEAB_Whitepaper040808.pdf

Jackson, S. J. (2009). Research methods and statistics: A critical thinking approach ( $3^{\text {rd }}$ ed.). Belmont, California: Wadsworth, Cengage Learning.

Joy, C. (2014, June). Descriptive method. Retrieved November 8, 2017, from https://prezi.com/3rdptjum29u9/descriptivemethod/

Koltay, T. (2011). The media and the literacies: Media literacy, information literacy, digital literacy. Media Culture Society, 33(2), 211-221. doi: 10.1177/0163443710393382

Malik, R. S., \& Hamied, F. A. (2014). Research methods: A guide for first time researchers. Bandung: UPI Press.

Muir-Herzig, R. G. (2004). Technology and its impact in the classroom. Computers \& Education, 42, 111-131. doi: 10.1016/S0360-1315(05)00067-8

Nowell, S. D. (2014). Using disruptive technologies to make digital connections: Stories of media use and digital literacy in secondary classrooms. Educational Media International, 51(2), 109-123. doi: 10.1080/09523987.2014.924661

Oblinger, D. \& Oblinger, J. (2012). Is it age or IT: First steps toward understanding the net generation. Retrieved October 1, 2012, http://www.educause.edu/research-andpublications/books/educating-net-generation/itage-or-it-first-stepstoward-understanding-netgeneration

Park, S.,\& Burford, S. (2013). A longitudinal study on the uses of mobile tablet devices and changes in digital media literacy of young adults. Educational Media International, 50(4), 266-280. doi: 10.1080/09523987.2013.862365

Prensky, M. (2001). Digital natives, digital immigrants part 1. On the Horizon, 9(5), 1-6. doi:10.1108/10748120110424816

Raman, K., \& Yamat, H. (2014). Barriers teachers face in integrating ICT during English lessons: A case study. The Malaysian Online Journal of Educational Technology, 2(3), 11-19. Retrieved November, 8, 2017, from, http://files.eric.ed.gov/fulltext/EJ1086402.pdf 
Rein, D. (2000). What is Effective Integration of Technology, and Does it Make a Difference? Cupertino, CA: Apple Computer, inc. Retrieved on November 8, 2017, from

http://citeseerx.ist.psu.edu/viewdoc/download?doi $=10.1 .1 .493 .5211 \& \mathrm{rep}=\mathrm{rep} 1 \&$ type $=\mathrm{pdf}$

Salkind, N. J. (2017). Exploring research ( $9^{\text {th }}$ ed.). Harlow: Pearson Education.

Suwana, F., \& Lily. (2017). Empowering Indonesian women through building digital media literacy. Kasetsart Journal of Social Sciences, 38, 212-217. doi: 10.1016/j.kjss.2016.10.004
Williams, R. W. (2012). Digital immigrant teacher perceptions of social media as it influences the affective and cognitive development of students: A phenomenological study (Unpublished doctoral dissertation). Liberty University, Lynchburg, VA, The United States of America.

Young, R. (2008). Using technology tools in the public school classroom. Menomonie, WI: University of Wisconsin-Stout.

Zhang, H. \& Zhu, C. (2016). A study of digital media literacy of the 5 th and 6th grade primary students in Beijing. Asia-Pacific Education Researcher, 25(4), 579-592. doi 10.1007/s40299-016-0285-2 